\title{
Strategy for Growing the Business of Representative Office Company in Iron and Steel Industry
}

\author{
Herry Winarso and Anh Dung Do \\ Master of Business Administration, Institut Teknologi Bandung, Bandung \\ e-mail: hwins@live.com
}

\begin{abstract}
Iron and steel industry is among the essential strategic groups of the national industry since iron and steel products are not only raw materials for metal-based manufacture industries but also as pillars of development in infrastructure. The development of the iron and steel industry requires comprehensive handling; in the mastering of processing technology and the resources added value. The iron and steel industry is the "Backbone" in supporting the development of the national economy. Therefore, the Government's role becomes crucial in developing the national iron and steel industry. Initially, the Indonesian steel industry was the largest in ASEAN, however over time, the position of Indonesian declines and no longer the largest. DAN is one of the three top manufacturers of plants and machines for the steelmaking industry in the world. The unavailability of adequate government protection to domestic producers made imported steel products streamed heavily in all upstream and downstream sectors. This situation made the steel producer cannot grow and become stagnant in income; it cannot compete in costs; therefore, cannot invest and innovate effectively. The unavailability of the significant investment made DAN business in Indonesia become tough to grow. The purpose of the research is to develop a business strategy for DAN representative office to grow its business in Indonesia and choose a value proposition to the Indonesian market. To achieve the research objective, data collection in the method of interviews into Indonesia iron and steel industry stakeholders, along with a direct survey questionnaire into the experts to understanding industry situation and stakeholders' perspective of DAN overall performance. The various analysis framework, named PESTEL, Five Forces Porter, SWOT, were utilized to understand Indonesia iron and steel market, and company internal advantages and disadvantages in responding to it. The result of strategies is implemented with sequences: costing evaluation, financing support, human resources, partnership development, and investment.
\end{abstract}

Keywords-Business Strategy, Iron and Steel industry, Steel Plant Making, Representative Office.

\section{INTRODUCTION}

\section{A. Background}

$\mathrm{T}$ HE development of the iron and steel as the "Mother of Industry" requires comprehensive handling, especially in the mastering of processing technology and improvement of the added value of the resources to guarantee effectiveness, efficiency, and continuity of the domestic industry. The illustration of the substantial role of the steel industry as the driving force of the other industries, whether backward (inputting industry) and forward (steel product user industry), can be observed in the following illustration.

\section{B. Problem Statement}

Initially, the Indonesian steel industry was the largest in ASEAN, however over time, new industries came in, causing the position of Indonesian decline and no longer the largest. In southeast Asia Iron and Steel Institute there are only six countries currently having steel industry; Indonesia, Malaysia, Philippines, Singapore, Thailand and Vietnam, and four donator countries; Australia, Japan, South Korea, and Taiwan, illustration on the development of production are shown in Figure 2.

The global steel market and Indonesia following are currently under the era of uncertainty and within the condition of "New Normal." Back during 2015, 2016, and 2017, there was a severe global crisis that caused steelmakers to reduce not only their new plant investments but also the purchase prices of new plants. Consequently, this impacted the plant makers also suffered due to under-absorption of fixed costs and narrow sales margins. The fixed cost of plant maintenance also reduced that made the steelmakers change their mindset to price-over-quality that made the $2^{\text {nd }}$-grade brand quality plant-maker was chosen over the top-quality plant makers such as DAN.

\section{Research Objective}

1. To define the new business strategy for improving the business of the representative office B.U.T DAN in Indonesia.

2. To define the new strategy for product and innovation that representative office B.U.T DAN Indonesia should implement in Indonesia.

3. To define the best legal structure of the company for the future, under which collaboration and alliance with the Indonesian steel producers and stakeholders are possible.

\section{Literature Review}

Strategic management is the integrative management field that combines analysis, formulation, and implementation in the quest of competitive advantage. Mastery of strategic management enables us to view a firm in its entirety. A good strategy consists of three elements [1].

Diagnosis of competitive challenge. This element is accomplished through an analysis of the firm's external and internal environment (Part 1 of the AFI framework). 


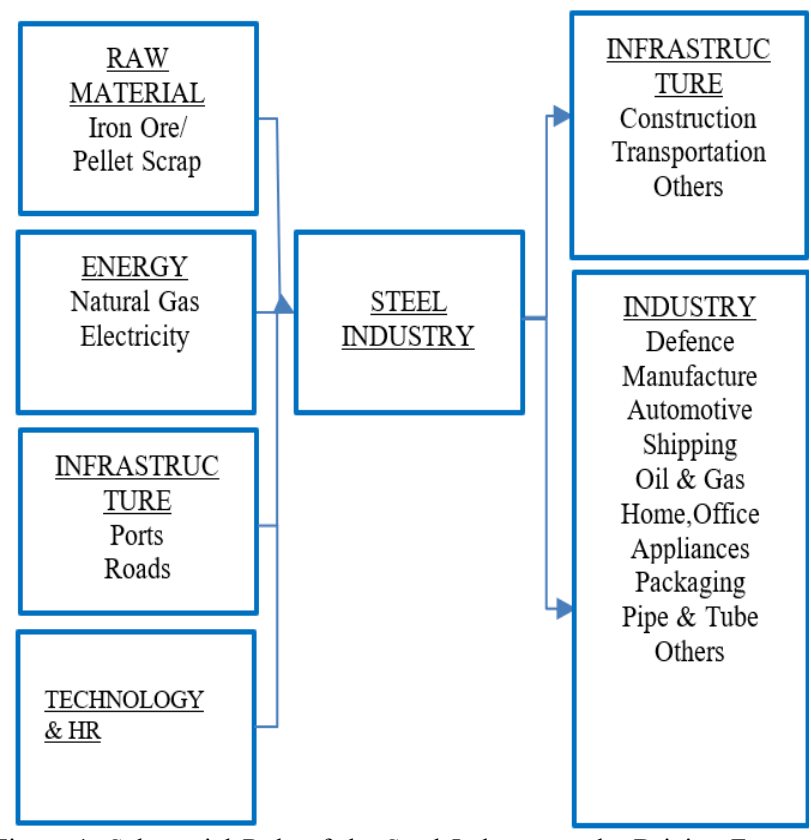

Figure 1. Substantial Role of the Steel Industry as the Driving Force of Other Industries.

Guiding policy to address the competitive challenge. This element is accomplished through strategy formulation, resulting in a firm's corporate, business, and functional strategy (Part 2 of the AFI framework).

Set of coherent actions to implement the firm's guiding policy. This element is accomplished through strategy formulation (Part 3 of the AFI framework).

Therefore, creating a sound strategy following these three steps are crucial. First, a good strategy defines the competitive challenges facing an organization through a critical and honest assessment of the status quo. Second, a good strategy provides an overarching approach on how to deal with the competitive challenges identified. The approach needs to be communicated in policies that provide clear guidance for all employees involved. Last, a good strategy requires effective implementation through a coherent set of actions [1].

Established in 1914, DAN S.p.A. designs, manufactures, and installs machines and plants for the metal industry covering the entire production cycle, from ore to a wide range of finished steel products, both on turnkey and single unit supply basis. DAN is one of the three top manufacturers of plants and machines for the steel-making industry in the world. It is the world leader in minimills and facilities for the production of long products, and second in flat products.

Vision:

Passionate and inspired people to build a stronger, sustainable future. The trustable partner for our customer's success.

Mission:

DAN is a full-cycle provider from raw material to finished products in the metals industry.

We are a sparkling multicultural team with in-depth knowledge of our business.

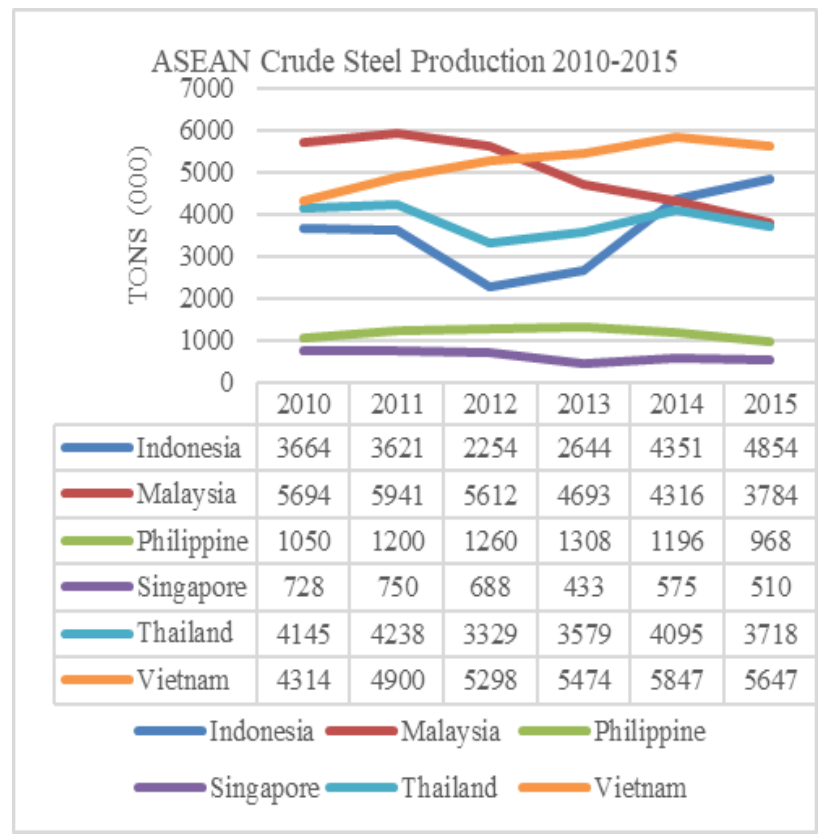

Figure 2. ASEAN Crude Steel Production Growth in Comparison.

Our professional life is dedicated to understanding and satisfying customer's needs through our experience, continuous team-up, and flexibility. We turn ideas into endto-end solutions of technological excellence to create added value for our customers and stakeholders.

We empower people, our main asset, with courage and creativity.

DAN activity as a representative office (B.U.T/Badan Usaha Tetap) in Indonesia was established in 2012. However, DAN already has various activities in Indonesia, with sales managed from a foreign entity with milestones can be described as follows:

1972, DAN had supplied steel plants in the form of greenfield long-product steel plants with 300.000 ton per year capacity in Pulogadung, Jakarta that also known as the very first private company that produces steel in Indonesia.

1976, DAN had supplied a greenfield steel plant of a wirerod mill with 60,000 tons per year capacity for PT. Ispat Indo, which was known to be the first company established by Laksmi Mittal, that later known as worldwide "King of Steel." Ispat Indo mill was the foundation of the establishment of the Arcelor Mittal group.

1980, DAN had supplied intermediate, and finishing stands for PT. Krakatau Steel wire rod with 300,000 ton per year capacity and reinforced bar steel plant with 500,000 ton per year capacity.

1992, DAN had supplied a continuous billet caster machine for PT. Interworld Steel Mills with 150,000 ton per year capacity to produce construction-grade steel billet.

1994, DAN had supplied plain and reinforced-bar steel mill for PT. Interworld Steel Mills with 250,000 tons per year capacity.

2004, DAN had supplied plain and reinforced-bar steel mill for PT. Tunggal Jaya Steel with 500,000 ton per year capacity. 


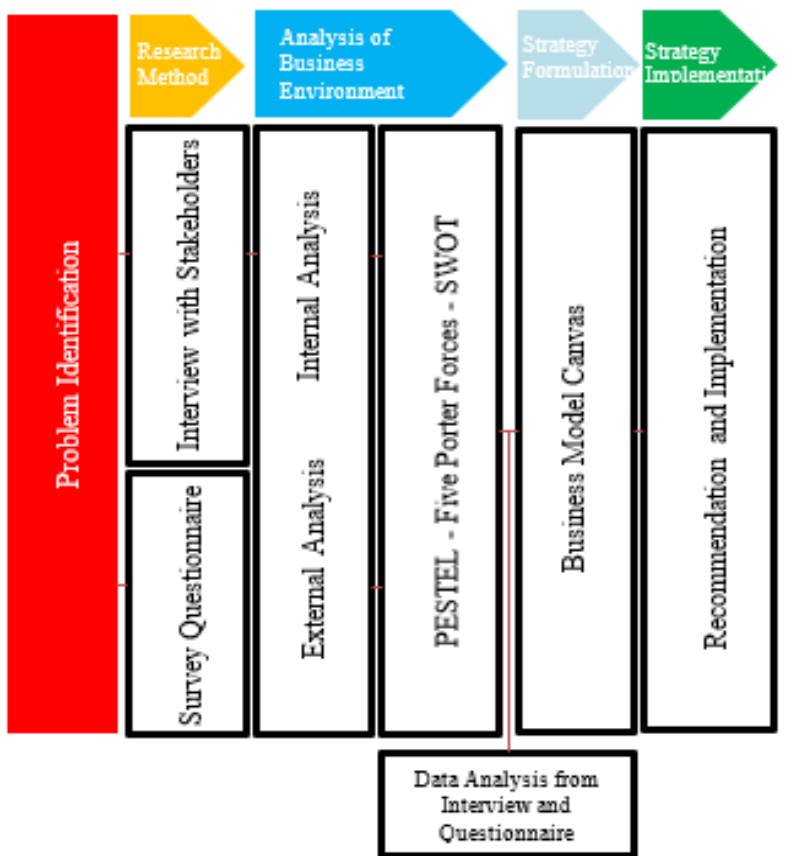

Figure 3. Strategy Research Conceptual Framework

2012, DAN had involved in a mega tender project of PT. Krakatau Steel for the establishment of Hot Strip Mill\#2 with a capacity of 1,5 million tons per year.

2017, DAN awarded to supply Cold Rolling Mill complex of PT. Sunrise steel with a capacity of 200,000 tons per year and push-pull pickling line with a capacity of 600,000 tons per year.

\section{METHOD}

\section{A. Research Design}

Research design is utilized to develop the research strategy; to integrates all elements in research to answer the research question and fulfill the research objective - the nature of the research design utilized is a qualitative methodology. Internal assessment is critical to define the best legal structure for DAN Indonesia and the feasibility of it. External assessment from customers and experts in the Iron and Steel industry are essential to construct the right strategy for the business development and choose products and innovation that best introduced in the Indonesia market from out of many DAN group products and innovation available. Aside from Primary data obtained from interviews and questionnaires, secondary data are collected from various sources of reports, books, and relevant articles.

Primary and secondary data were utilized in this research in order to conduct the analysis. Here are the methods to gather the data:

\section{1) Primary Data}

a. Direct interview face-to-face with stakeholders

Interviews were conducted with 20 persons whom essential stakeholders in the iron and steel industry along with DAN's internal company structure, which is consist of; management of DAN HQ Italy and DAN Indonesia (5 persons; 3 Italian nationalities, 1 Philippine nationality and 1 Indonesian nationality with experiences varies from $8-29$

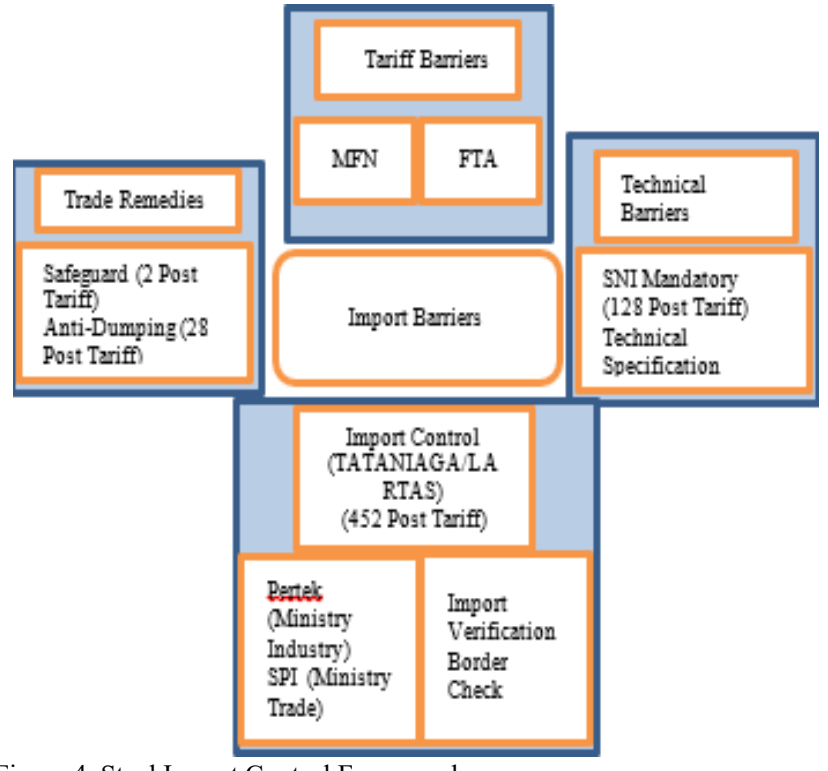

Figure 4. Steel Import Control Framework

years), customers and experts in Indonesia Iron and Steel Industry (15 persons; 8 Indonesian nationality, 6 Indian nationalities, 1 Hong Kong nationality with experiences varies from 5 years -29 years). The interviewee profiles and roles are varying from the employee, expatriates, and owner of the steel-producing companies.

There are general and specific questions, the general question is related to respondent work experience, and their perspective of the steel industry globally and in Indonesia. The specific question is related to the respondent perspective to DAN performances, expectation, and their suggestion for DAN future business presence in Indonesia.

b. Direct survey questionnaire into Indonesia iron and steel industry stakeholders

Survey design is conducted to obtain optimum and to complement the result of the interview. In order to obtain optimum qualitative data, a questionnaire was distributed by direct appointment to stakeholders that already understand DAN equipment performances, therefore able to put an accurate score in DAN. In total, there are 40 expert respondents participate in the questionnaire.

2) Secondary Data

a. Established data provided by the company (DAN).

b. Established data published from books, articles, and other reliable sources.

\section{RESULTS AND DISCUSSION}

In prior of any strategy or tactical plan can be implemented, it is fundamental to conduct a situational analysis. PESTEL analysis covers from Politics; that the iron and steel industry in Indonesia is highly influenced by the global market situation, especially from China, due to China is the largest producer and consumer of steel in the world. Indonesia iron and steel are also profoundly affected by the situation in the downstream market, such as property and construction, which currently having stagnant growth.

Economics, Indonesia has positive growth with being the world's $10^{\text {th }}$ largest economy in terms of purchasing power 
The $1^{\text {st }}$ International Conference on Business and Engineering Management (IConBEM)

February $1^{\text {st }} 2020$, Institut Teknologi Sepuluh Nopember, Surabaya, Indonesia

Table 1.

Trade Remedies For Steel Products.

\begin{tabular}{|c|c|c|c|c|}
\hline Trade Remedies & $\begin{array}{l}\text { PMK(Ministry of Finance } \\
\text { Regulation) }\end{array}$ & Products & Post Tariff & Validity Period \\
\hline $\begin{array}{l}\text { Safeguard (Trade Security } \\
\text { countermeasure) }\end{array}$ & PMK No.2/PMK.010/2018 & I and H Section from alloy steel & $2 \mathrm{HS}$ & 21 Jan $2018-21$ Jan 2021 \\
\hline \multirow{4}{*}{$\begin{array}{l}\text { BMAD (Bea Masuk Anti } \\
\text { Dumping/ Anti-Dumping } \\
\text { Import Tariff) }\end{array}$} & PMK No.25/PMK.010/2019 & $\begin{array}{l}\text { Cantai Lantaian/Hot Rolled Coil from } \\
\text { Steel or Non-alloy }\end{array}$ & $15 \mathrm{HS}$ & 02 Apr 2019-02 Apr 2024 \\
\hline & $\begin{array}{l}\text { PMK } \\
\text { No.214/PMK.010/2018 }\end{array}$ & $\begin{array}{l}\text { Cantai Lantaian/Hot Rolled Coil from } \\
\text { Steel or Non-alloy plated or not with Tin }\end{array}$ & $2 \mathrm{HS}$ & 15 Feb 2019 - 15 Feb 2024 \\
\hline & PMK No.27/PMK.010/2018 & Steel Wire-Rod & $7 \mathrm{HS}$ & 17 Apr 2018 - 17 Apr 2021 \\
\hline & PMK No.24/PMK.010/2019 & I and $\mathrm{H}$ Section & $4 \mathrm{HS}$ & 02 Apr $2019-02$ Apr 2024 \\
\hline \multicolumn{3}{|c|}{ Total } & & $30 \mathrm{HS}$ \\
\hline
\end{tabular}

Table 2 .

Import Control (Tata Niaga/Lartas)

\begin{tabular}{|c|c|c|c|}
\hline $\begin{array}{c}\text { PERMENDAG } \\
\text { (Ministry of Trade Regulation) }\end{array}$ & Post Tariff & Instrument & Validity Period \\
\hline $\begin{array}{l}\text { Permendag No. } 82 \quad \text { /M- } \\
\text { DAG/PER/12/2016 }\end{array}$ & $\begin{array}{l}\text { Iron or Steel ( } 341 \mathrm{HS}) \\
\text { Alloy }(64 \mathrm{HS}) \\
\text { Downstream Product ( } 47 \mathrm{HS})\end{array}$ & $\begin{array}{l}\text { Import Approval (Ministry of Trade) } \\
\text { Import Verification (Surveyor) }\end{array}$ & $\begin{array}{l}1 \text { January } 2017 \text { - } 31 \text { December } \\
2019\end{array}$ \\
\hline Permendag No. 110 Tahun 2018 & $\begin{array}{l}\text { Iron or Steel (341 HS) } \\
\text { Alloy ( } 65 \mathrm{HS}) \\
\text { Downstream Product (47 HS) }\end{array}$ & $\begin{array}{l}\text { Pertek (Ministry of Industry) } \\
\text { Import Approval (Ministry of Trade) } \\
\text { Import Verification (Surveyor) }\end{array}$ & 5 January 2019 - Not defined \\
\hline
\end{tabular}

parity and continuous growth of above 5\%. However, this growth mostly only obtains from domestic consumerism that made Indonesia only as consumer, proven with Indonesia ranked $14^{\text {th }}$ in 2018 with total iron and steel imports of 11.7 million tonnes, and ranked $6^{\text {th }}$ in 2018 on net imports (imports-exports) with total net imports of 7.9 million tonnes.

Socials, Indonesia remained very potential with an annual growth of $1.04 \%$ on a population of over 270 million. Indonesia's iron and steel industry also still has plenty room to grow, due to Indonesia is the lowest consumer compare to other countries in the ASEAN region, with only $59 \mathrm{~kg} / \mathrm{per}$ capita in 2019.

Technology, Indonesia's steel consumption in 2016 is 12.70 million tons and is projected to be 21.40 million tons in 2025. However, in overall, domestic steel products are not competitive against imported because of the high structure of Cost of Goods Sold (COGS) due to overall Indonesian steel producing companies' technology that obsolete and falls behind.

Legal, Indonesia iron, and steel industry are having laws and regulations in place to protect it; in the form of import trade remedies and national standard (SNI). However, the implementation is still flawed.

Five Forces of Porter analysis points out that the most significant threat that is considered high is related to Bargaining Power of Buyers, and Rivalry Among Existing Competitors.

The bargaining power of buyers; due to the nature of steel plant making business is in highly technological equipment, and the price of new plant or equipment is considered high, with having only a few buyers also the current Indonesia iron and steel industry itself currently in a tough situation, therefore an investment opportunity is not too much.
Rivalry among existing competitors, DAN market remains tough that our equipment is used in all market leaders in long steel products, SMS Group remains market leaders in flat steel products, and Primetals as the Japanese company has remained tough with their presence in Major Japanese producer.

SWOT analysis points out that DAN has various strengths that can be utilized to lead the market; however, the weakness of high cost-structure and complicated business processes and products made DAN's competitiveness also reduce against the threat of fierce competition from competitors; whether another market leader or the $2^{\text {nd }}$ low-grade supplier.

\section{A. Conclusion}

Indonesia's iron and steel industry is very dynamic and affected by the situation of China as the world's largest producer and consumer. Since 2018 trade was has occurred between the US and China that made Chinese companies switch their export destination and plant investment plan into ASEAN and Indonesia.

Indonesia iron and steel industry market problem, are divided into each product;

Flat steel products problem is massive imports from China, in the form of half-finished products and downstream products which still import unprotected products, along with an illegal product that coming to cheat the import protected products with HS code manipulation.

Long steel products problem is very-low prices of finished products circulating in the market caused by the existence of low-grade Chinese investment plants in Indonesia that making a product in non-standard /non-SNI.

Massive imports of a half-finished product also occurred due to Indonesia melt shop producer cannot compete in price 
The $1^{\text {st }}$ International Conference on Business and Engineering Management (IConBEM)

February $1^{\text {st }} 2020$, Institut Teknologi Sepuluh Nopember, Surabaya, Indonesia

due to the lack of technology, resources, and no import protection for it. Therefore most producer-only operate rolling production, which transforms the half-finished product to finished-product and not operates melt shop, which transforms raw material into a half-finished product. This situation made the company only operates in a thin business margin.

Indonesia iron and steel companies mostly still operate in old technology and machinery, with many of it have operated with more than 30 years. This situation creates a production process that is having ineffective production yield, inefficient energy consumption, and low productivity. The steel plant market demand for new reliable, effective, and efficient technology and equipment is available. However, the overall market situation is bad and circulates in thin price margins. Therefore, steel producing companies are hesitating in making a capital investment for new plant and equipment.

DAN is a worldwide leading plant maker in the iron and steel industry, have known as a one-stop solution that can offer a complete line of equipment that started from upstream, such as the melting shop and scrap processing line into downstream such as coating lines and shearing lines. DAN is strong in research and development; therefore, able to present various technological packages and solutions in tailor-made to help customers obtain and retain a competitive advantage.

DAN in Indonesia has been known since the 1970s however, due to the economic crisis in the 1990s began losing market portion and cannot retain the growth. DAN is known to be the undisputed world's best supplier in long steel products and second-best world suppliers in flat steel products.

Despite the excellent brand and performance, DAN is also known in Indonesia stakeholders to be a premium segmented supplier with high prices both for capital investment or spare parts and services. Another DAN weakness also in the delivery time that is known to be very long in spare parts, that the average is around four months.

DAN representative office Indonesia's presence is well known and supporting well in long steel products projects and help to obtain projects in flat steel products. Despite its structure that currently only consisted of 2 persons doing Key Account Management roles in promoting DAN's new equipment and spare part services.

In order for DAN Indonesia to develop its structure further from B.U.T/representative office to P.T./limited company; consideration in term of order intake (order intake is divided between new plant project and spare part services) and business sustainability is required; also comprehensive evaluation of the benefits is necessary therefore the company will help in giving reduction in cost structure and not in contrary add extra costs that affected DAN price competitiveness in Indonesia.

DAN Indonesia's office currently is known for giving the renowned premium perspective of DAN to be more price competitive. However, clients are on demand for larger human resources, especially in terms of giving daily technical support for an operational and maintenance problem.

In terms of the product, DAN can push its leading no. 1 worldwide products for long products such as wire rod mill, bundling station, and mill stand, along with its melt shop plant and equipment that known to be able to create competitive advantage in having low transformation operation costs and energy consumption. For example, the saving can be obtained shop in 2 million tonnes of crude steel production from technological differences between new melt shops against the old melt are 60 million USD.

DAN can create the blue ocean market with numerous of its radical innovations, such as Q-One, which can replace the function of transformers and Q-Melt that able to provide industrial 4.0 function in melt shop with considered low investment.

DAN services and spare part business also known to be reliable that precise and heavy-duty in performance, with a line of products such as a gearbox, gear, roller guide, and blade. Its lifetime is considered long compare to parts from the $2^{\text {nd }}$-grade supplier. However, its price competitiveness needs to be further evaluated.

DAN Automation is essential to connect to industrial 4.0, with the capability to provide plants to be operated and analyzed in real-time with more productive and able to reduce operational costs and avoid excessive waste in terms of products, working hours or maintenance.

Refer to the survey questionnaire result, DAN obtain the highest score in stakeholders' perspective that Danieli is the state-of-the-art technological provider in the steelmaking business (8.67) and followed that their high likeliness to recommend DAN's equipment to their friend and colleagues (8.51).

However, the weakness is stated in DAN's commercial prices as the lowest score (6.31), DAN presences in Indonesia is not yet satisfying (7.15), DAN still needs to improve its communication and support for daily operation and project (7.31), and DAN delivery time needs to be improved (7.38). This questionnaire results matched well with the interview result.

Refer to business canvas analysis, DAN has numerous advantages in value propositions, that it is owned full complete lines of products downstream to upstream, flexibility in offering a large turnkey project to single spare part, and even only consultancy services. DAN has a big manufacturing plant near in Thailand that the logistic costs are considered good. DAN's channels also have been utilized effectively to convey information and communication to clients.

However, DAN can still be improved in term of key activities and key partnership, DAN can start to evaluate partnership development with local suppliers, contractor, and workshop with more comprehensive. Therefore, it can be additional advantages to DAN in their new plant project bidding and daily services business, i.e., improve its delivery time to clients.

\section{B. Recommendation}

Based on the result of the analysis of previous chapters, seven points were obtained, which should be taken into consideration in developing DAN's business in growth in Indonesia: 1. Indonesia iron and steel industry market situation, 2. Rivalry among competitors, 3. Pricing, 4. Human 
The $1^{\text {st }}$ International Conference on Business and Engineering Management (IConBEM)

February $1^{\text {st }} 2020$, Institut Teknologi Sepuluh Nopember, Surabaya, Indonesia

resources, 5. Delivery time, 6. Communication and Support,

7. Local partnership development.

The essential and foremost priority is to improve costcompetitiveness. This is important in the Indonesia iron and steel industry market situation that in stagnancy, facing massive import of flat steel products and low prices circulating in long steel products. Therefore, specific and comprehensive costing for the Indonesia market should be conducted, both on new plant projects and services spare parts. Therefore, DAN could capture the market first in terms of the number of plant references and clients. Then afterward, the references can be utilized to maintain business sustainability by order intake of the services business and client's continuous technological improvement.

DAN could also be giving an attractive financial scheme for the new plant project with an evaluation of the clients is a long-time client of DAN, the client's healthy financial situation, and or clients is a state-owned company.

In conjunction with improving cost-competitiveness, DAN's current structure in Indonesia should be effective and efficient. Therefore, DAN Indonesia is preferred to be maintained as a representative office in Indonesia in the meantime. Growth in the company structure to be the limited company; should be an in-detail evaluation that will improve the cost competitiveness, such as 1. along with the establishment of services and spare part workshop and or 2 . technical and procurement office to communicate with the local supplier in case of the large project obtained.

In the meantime, the following client's daily technical, operational needs and to follow up further bidding process with better. DAN Indonesia could increase the number of human resources for technical support expert, the recommendation for the expert should be in mid-to-senior experiences that have been used and understand DAN's product well and understand its advantage. The expert could be obtained from the long-time client's employee or better from DAN's internal employee as an expatriate.

Partnership development with local suppliers and workshops should also be considered well; it can be started as first to taking care of the service and spare part business, so the delivery time and prices can be improved, and it the end increases the number of order intake.

\section{REFERENCES}

[1] Frank, T. Rothaermel, "Strategic Management", 2017, McGrawHill Education.

[2] South East Asia Iron and Steel Institute, "Indonesia Country Report 2018”, 2018, Conference and Exhibition Indonesia.

[3] The Indonesian Iron and Steel Industry Association, "Indonesia Steel Industry: Development \& Opportunities, Paris $29^{\text {th }}$ Sept 2017.

[4] World Steel Association, "World Steel in Figures 2019", 2019.

[5] World Steel Association, "Short Range Outlook October 2019", 2019.

[6] Tan Ah Yong, "SEAISI Newsletter October 2019”, 2019, Secretary-General Tan Ah Yong

[7] Di Maggio, "Looking at the plant engineering market: Danieli, Primetals, SMS Group", 2017.

[8] Source:https://www.expometals.net/en-gb/news/news-indetail/looking-at-the-plant-engineering-market-danieli-primetalssms-group-id18629

[9] Danieli, "Danieli Year 2018”, 2018.

[10] OECD Economic Outlook, Volume 2018

[11] http://worldpopulationreview.com/countries/indonesiapopulation/

[12] https://www.statista.com/statistics/273634/nickel-reservesworldwide-by-country/

[13] https://www.nickelinstitute.org/about-nickel/

[14] https://www.worldbank.org/en/country/indonesia/overview

[15] http://www.oecd.org/economy/outlook/economic-forecastsummary-indonesia-oecd-economic-outlook.pdf 